\title{
Who is Carl Zeiss?
}

\author{
by our Special Correspondent
}

\section{Jena, February.}

As a source of street names in eastern Europe, Karl Marx is rarely challenged. In the East German town of Jena, however, he is outdone by two local figures, Carl Zeiss and Ernst Abbe. Together these two created the firm of Carl Zeiss of Jena, manufacturing optical and fine mechanical instruments. Under Abbe's influence the company became philanthropic, and fits comparatively easily into the socialist system, but it has a history of adapting to circumstances. Before the Second World War, it supplied equipment to the German armed forces, as the present managers gloomily admit. Since then, they insist, no military equipment has been made at Jena. The company, now nationalized, makes 4,000 items (excluding its range of 200,000 spectacle lenses) and sells them throughout the world, despite considerable harassment in capitalist countries.

The instruments made by Zeiss of Jena fall into two categories, optical and metrological. The optical glass is made at Jena, by processes jealously guarded but which seem to owe more to 120 years of empiricism than to modern control technology. Apart from its well known microscopes-the latest, the all purpose "Nu", operates either with reflected or transmitted light (or with both at once), has a pancratic (zoom) lens and all the usual facilities, and sells for about $£ 2,000$ in the United Kingdom-the company produces surveying instruments, refractometers, interferometers spectrophotometers, and the like. Zeiss also make binoculars and cameras, and a range of measuring equipment less directly useful to scientists.

Zeiss of Jena find it more than usually hard to trade with the West. In addition to the indignities caused by cold war diplomacy, there is confusion, to say the least of it, over the use of the Carl Zeiss name. When Jena became part of the Russian sector, a number of Zeiss workers, encouraged by the departing Americans, defocted to the West. Claiming the right to move the Carl Zeiss Foundation to Heidenheim, a small town near Ulm in West Germany, the emigrees started production in Ober Kochen, and were supported by a ruling from a West German court. The range of equipment produced by Zeiss of Ober Kochen is similar but, says Jena, less comprehensive. After a difficult start, the Ober Kochen concorn has flourishod, aided by Jena's early pre-occupation with the eastern market. In recent years Jena has been expanding its business in the West, and this has brought the conflict into the open.

Judgments in favour of the Ober Kochen concern in West Germany, Austria and the Netherlands are balanced by judgments in favour of Jena in East Germany, Czechoslovakia and Yugoslavia. Ober Kochen does not market its products in eastern Europe, but Jena continuo to market in West Germany under the trade name "Aus Jena". Advertising by either concern, apart from adding to tho legal confusion, tends to rebound to the advantage of the other side. In the United Kingdom the battle is in a state of suspended animation, after a High Court decision last year establishing the right of Jena to be represented. Ober Kochen had argued that the absence of diplomatic relations between Britain and East Germany prevented legal representation of Jena in a British Court. Jena, prodictably, is full of praise for the British judicial systom, and may feel sufficiently encouraged to go ahead with a full scale civil action. In the

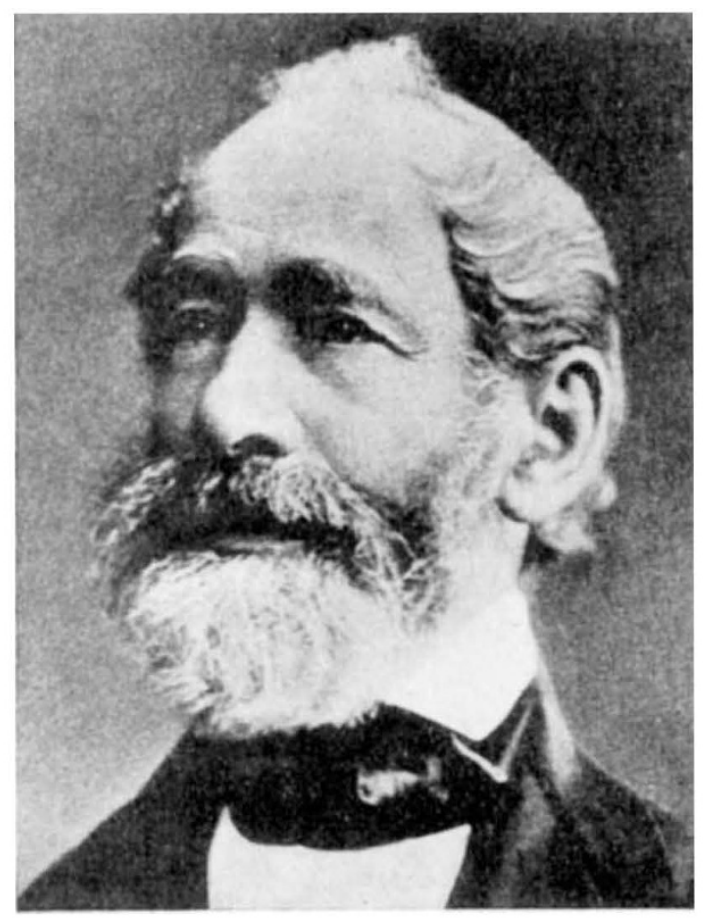

United States the Ober Kochen concern is dominant, because Jena, unable to obtain visas to send service engineers, will sell only their smaller equipment there. In Canada, the city of Montreal was recently presented with an Ober Kochen planetarium, while the Royal Ontario Museum bought one from Jena.

Carl Zeiss of Jena occupies a special position in the East German economy. Nationalized in 1949, it employs more than 20,000 people and is the largest centre of research and development in the country. Unlike most East German concerns, it operates its own overseas marketing organization, and its success-it is the largest earner of foreign currency in the country-may enable other East German companies to obtain the same privileges. In the home market it is obliged by law to make a profit on every item it sells, but abroad this control is lifted, and Jena is able to undercut competitors, sometimes by as much as 30 per cent.

Research at Jena scoms concentrated in product development. Ernst Gallerach, Director General of the company since August 1966, refuses to make any distinction between pure and applied research. "Pure science does not exist; it exists only when implemented", he says. This means that while the firm retains its traditional strength in classical optics, it is slow to adopt anything newer. Lasers and fibre optics have been taken up rather half-heartedly, but holography is dismissed as an acadomic toy. For market research, the company relies on careful reading of the literature, conversations with customers and information from university sciontists in East Germany. It noeds to be convinced that an instrument is thoroughly reliable and commercial before it will set about designing it, and hence tends to leave important basic research work to companies in the West. The company has recently beon re-organized, and as part of this plan is buying a computer from International Computers and Tabulators. Western computer manufacturers need not reach for thoir passports, however; Mr. Gallerach says that most future purchases by East Germany will be from the Soviet Union. 